\title{
Engravist Istanbul Ex-libris Engraving Workshop
}

Res. Asst. Zeliha Kayahan Ankara Hacı Bayram Veli Üniversitesi University
The Faculty of Fine Arts The Departmant of Basic Art Sciences zelihakayahan@gmail.com

Full Length Paper Accepted 10 July 2018

\section{Abstract}

With the discourse of Prof. Hasip Pektaş, name of whom we often hear in our country for his efforts to introduce and spread Ex-libris art; "Ex-libris is deed of the book". These small scale works, which have gone through many changes/transformations both in the meaning and technical aspect as of BC. 1400's until today, have made quite a name in recent years and attract even the attention of non-field people with international contest and collecting field. In this context, a workshop of the International Engravist Istanbul Gravure Workshops Event which was performed in Yıldız Technical University in 2017, was allocated to Prof. Hasip Pektaş and his Ex-libris works. General theme of this workshop, which has the characteristics to be the first in its field, is based on "Istanbul Engravings". In the Ex-libris workshop performed in Yildiz Technical University Art and Design Faculty Engravist Atelier, the participants applied their designs with the linoleum printing technique. As a result of the event, all the works arising as a result of engravist events which opened their doors to students and young academicians whether or not knowing how to print from all over Turkey and start with the slogan "Gravure 40 Days 40 Nights", were brought together with audiences through a mixed exhibition.

As one of the participants of this workshop which took place in 2017, I had an interactive training week covering the application dimension of the technique as well as information on the historical development and use of Ex-libris art. In this context; this work has its basic purpose of documenting the workshop process and sharing its achievements. The study is quite meaningful in terms of the increase of interest in Ex-libris in our country and the reflection of cultural values on artistic practices.

Key words: Ex-libris, Engravist, Linol Print, Hasip Pektaş. 


\section{Introduction}

According to Hasip Pektaş, the president of Istanbul Ex-libris Association, which was founded in Ankara in 1997 and continues to work in Istanbul as of the year 2008 until today; the most simple definition of Ex-libris is "business card or deed of book ". Ex-libris is a Latin word meaning "the book of ...", "... belongs to the library of ..." or "... belongs to the library of ..." (Pektaş, 2014a: 11). Ex-librises are small, original works of art that are adhered to the inner lid of books by the bookish person, on which the name of the book's owner and related or varied pictures are present (Kaynar, 2006: 4).

The art of Ex-libris helps the person who borrows the book or finds the book in case the book is lost because it is evidence that the book belongs to the owner, or warns and protects the book against theft (Ardahanlı, 2015: 86). Ex-libris can be made for everyone. However, it should not be forgotten that there is no tourism intended Ex-libris and on behalf of a dead person in the world. Ex-libris can only function if it is done on behalf of living persons and institutions (Pektaş, 2014b:5).

From their first appearance during 1400's until today, the meaning and use patterns of Ex-librises have changed. Innovations in technical applications, along with the invention of the changing age, lead to the creation of more modern Ex-libris designs. Ex-librises have an artistic value outside the function of the book. For this reason, it can be exhibited as an original graphic and painting work and can enter collections. There are some features that an Ex-libris should have. Ardahanlı listed these features in his work as follows:

- The name of the book or library owner,

- If already known symbol,

- The word "Ex-libris"

- An appropriate expression or promise,

- The order number and location of the book,

- Date and source of book acquisition,

- The sign and the symbol of the artist who designed the Ex-libris,

- Print date and print technique mark,

- Production number in the printing order (Ardahanlı, 2015: 86).

Ex-librises are mostly made on request. The artist carries out his / her design by knowing the wishes and the interests of the person (Pektaş, 2014a: 55). Ex-libris can be made in a wide variety of subjects and contents. It is possiple to find figure, abstract, woman, erotic, music, plant, animal, technology, butterfly, history, landscape, family and professions etc. in Ex-librises. Every Ex-libris artist can do his or her work with a focus on the 
subject he wants with his preferred technique. Anatoli Kalaschnikaw, the Russian Ex-libris artist, produces works on linoleum printing technique (Image 1,2,3). Although the works have different topics, the artist created a unique style in his works with his technique and style.

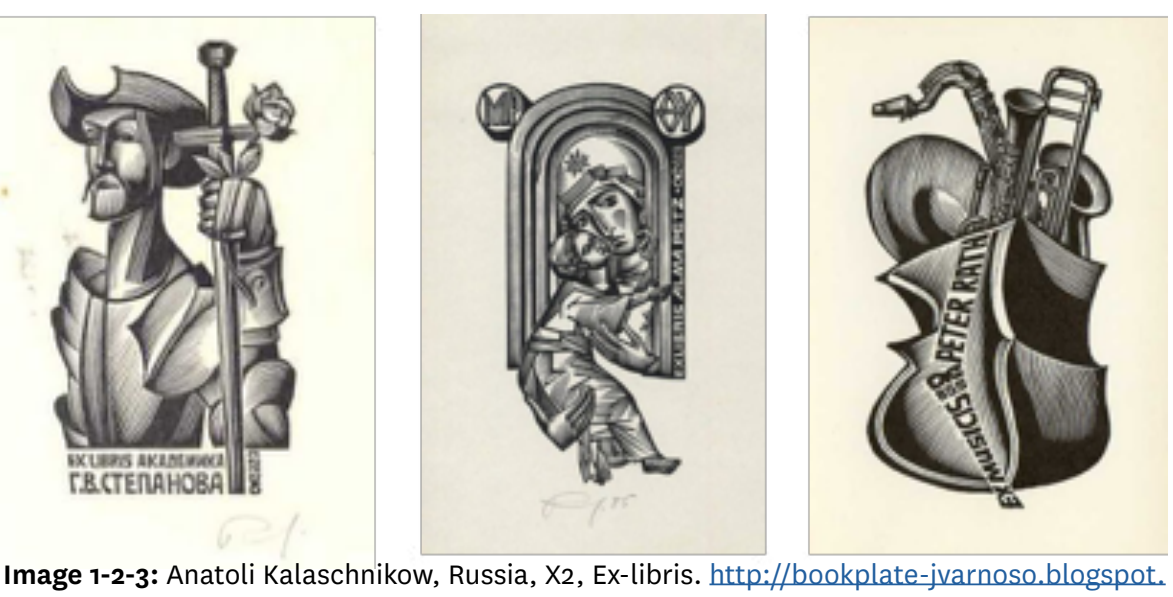

Okur (2013) thinks Ex-librises as a means of communication in his work. "In such a model, he believes that the person who ordered the Ex-libris can be considered as the 'source', the artist as the 'sender', the Ex-libris as 'communication medium' and those who use the book containing this Exlibris as 'recipients' (Okur, 2013: 42). Okur avoids evaluating Ex-libris in the same meaning with any communication tool. According to him, Ex-libris has the functions of aesthetic worry and being in a communication. Even though the recipient is catching one of these two functions, he interacts with that artwork.

\section{International Engravist Printmaking Events}

International Engravist Printmaking Events Workshop is an event founded and directed by Assoc. Dr. Lütfü Kaplanoğlu of Yıldız Technical University, Faculty of Art and Design. It is an exhibition project which is composed of 8 international workshops with the theme "Istanbul Engravings" (Engravist. com, 2017).

During the workshops planned in the framework of this activity, international artists expressed their impression of printmaking with their applications. In the workshops, the artists first taught their techniques with participation, and then the participants produced works in this direction. The event/ project was concluded with the presentation of an exhibition consisting of the works which were produced at the end of the workshops, each consisting 
of different technics, to a large audience.

\section{Workshops and Chair}

1. Photo Engraving Workshop Chair: Assoc. Dr. Musa Köksal

2. Drypoint Gravure Workshop Chair: Assoc. Dr. Erhun Şengül

3. Color Engraving Workshop Chair: Assoc. Dr. Burhan Ahmeti Multicolor

4. Gravure Workshop Chair: Prof. Dr. Fehim Huskovic

5. Aquatint - Mezzotint Gravure Workshop Chair: Prof. Trajche Blazhevski

6. Ex-libris Gravure Workshop Chair: Prof. Hasip Pektaş

7. Nontoxic Gravure Workshop Chair: Prof. Melihat Tüzün

8. Woodcut Gravure Workshop Chair: Prof. Dr. Hatice Bengisu

These workshops with "Istanbul Engravings" topic are important in terms of introducing our country in the international arena and developing/ spreading the art of gravure in our country, while enabling to produce many engravings of Istanbul, the city which is a source of inspiration for a large number of artists with its beauty, cultural history and civilizations established on it (Engravist Exhibition Catalogue, 2017).

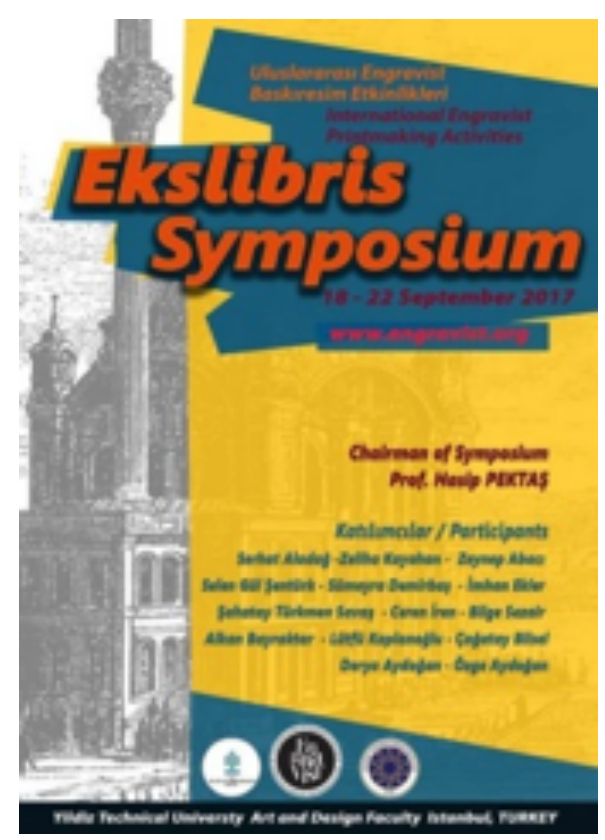

Image 4: Ex-libris Engraving Workshop

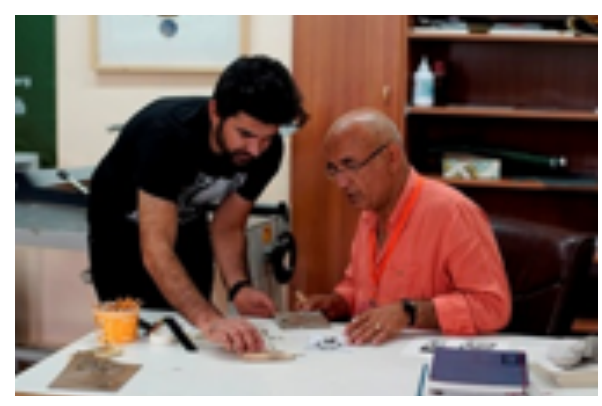

Image 5: Image from Ex-libris Engraving Workshop, 2017

\section{Ex-libris Engraving Workshop with Professor Hasip Pektaş}

One of the workshops planned within the scope of International Engravist Printmaking Activities was the Ex-libris Gravure Workshop, chairman of which was Prof. Hasip Pektaş. 14 participants included in the event that took place between 18-22 September 2017. With a mixed group of participants from different fields and departments, theoretical knowledge about Ex-libris history and techniques has been acquired as well as practical application of Ex-libris art.

The print is based on the transfer of pictures, feelings and ideas to another surface through patterns and the availability of multiple copies. In this art field based on multiplication, the stages which the visual desired to be conveyed goes through, how many prints are obtained and designer identity of the artist who manages all the printing stages are very important (FırıncI, 2013: 128). Ex-libris studies can be applied with different printing techniques because of the necessity of being reproducible. In addition to techniques such as steel engraving, wood printing, lithography, linoleum printing, aquatint, dry scraping, mesotint, computer assisted programs and Ex-libris studies can be done. The preferred method in the Ex-libris Gravure Workshop was the linoleum printing technique. 

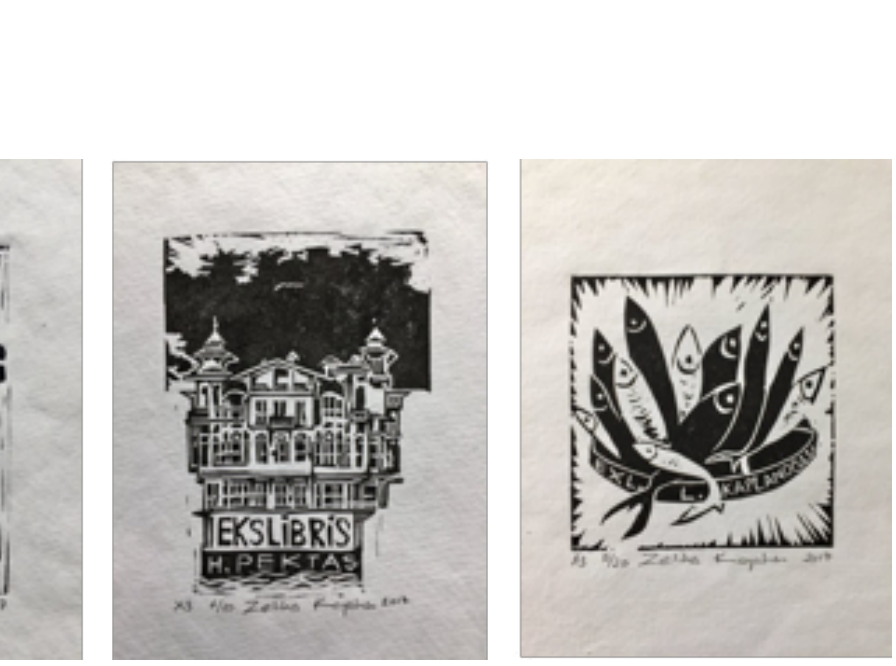

Image 6-7-8: Ex-libris of Istanbul belonging to Zeliha Kayahan from Ex-libris Workshop, 2017.

Linol printing technique is in the group of high printing techniques. There are many reasons why linoleum printing is preferred. These are; ease of workshop equipment, ease of application of tools and equipment, easy processing of materials; linoleum being distinctive, unique at the time of working, suitable to creative values and under the control of the artist during application (Karakaş, 2006: 83). According to Pektaş, the carving process can be carried out in every direction in linol printing technique and very effective results can be obtained especially in black and white prints (Pektaş, 2014a: 71). In case the material is inexpensive and there is a mistake, the linol printing allows the working artist to think practically in order to offer alternatives such as addition and subtraction. "The longevity of linolear molds, ease of storage, cleanliness and ease of processing have expanded the application range of this printing form"(Beykal,2012: 191).
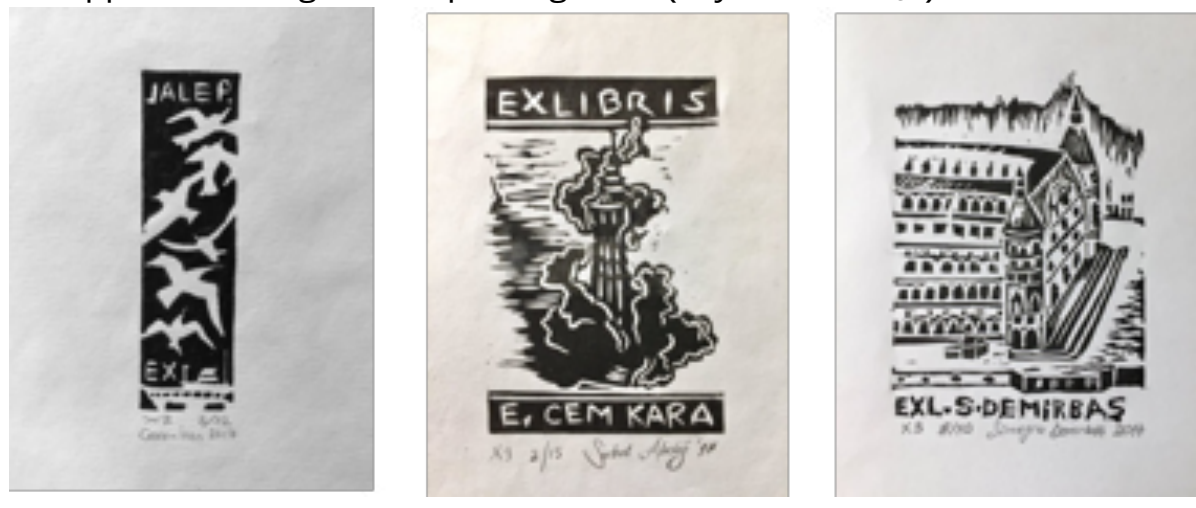

Image 9: Ex-libris of Istanbul belonging to Ceren iren from Ex-libris Workshop, 2017. Image 10: Ex-libris on Istanbul belonging to Serhat Akdağ from Ex-libris Workshop, 2017. Image 11: Ex-libris on Istanbul belonging to Sümeyra Demirbaş from Ex-libris Workshop, 2017.

The works within the event started with the presentation of Prof. Hasip Pektaş about Ex-libris. Subsequently, this was followed by application dimension of the designs prepared by participants. The stage for application of the technique has begun after passing the designed work to the linol surface. Afterwards, the white areas are removed by carving out the desired 
texture and then the upper parts remaining on the mold surface are painted with a roller and printed on paper. After the prints got dry, the identity writing section was initiated. In the Ex-libris studies, the linoleum press symbol is shown as $\mathrm{X}_{3}$.

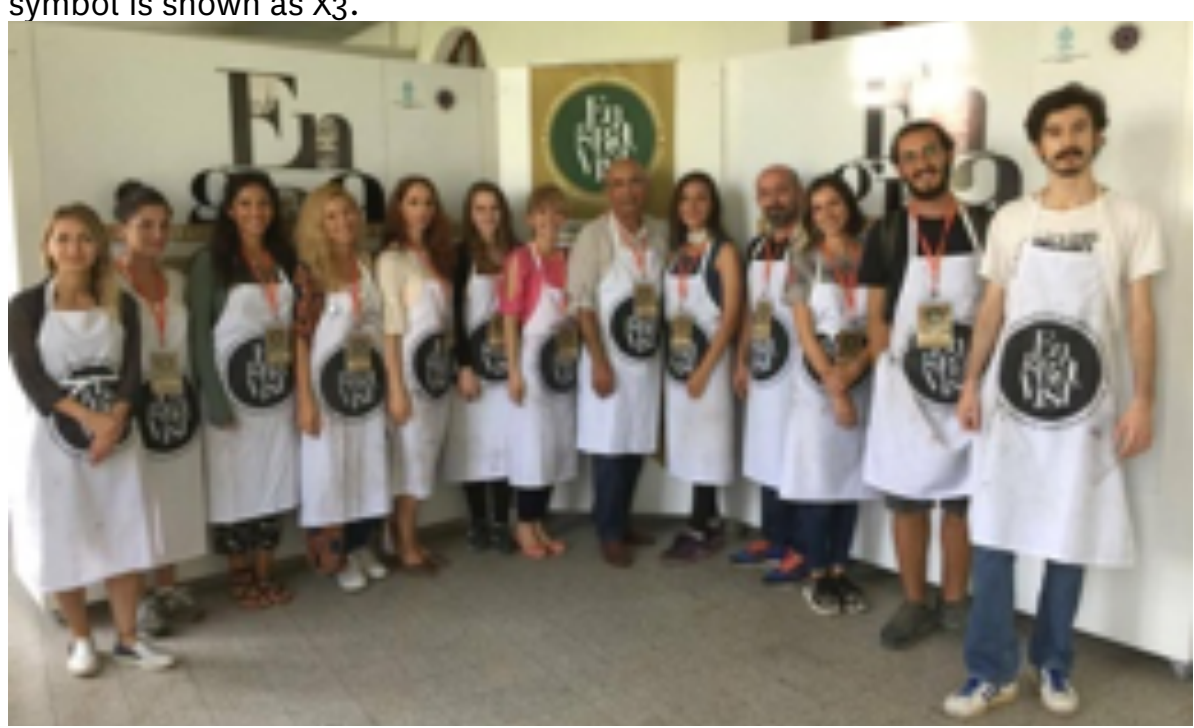

Image 12: Ex-libris Engraving Workshop Chairman Prof. Hasip Pektaş and Workshop Participants, 2017

At the end of the workshop, all works appeared in 8 workshops that were realized as part of the International Engravist Printmaking Events were delivered to the Engravist Exhibition in which Istanbul was reinterpreted with printmakings and held at Trump Art Gallery between 10 October and 6 November with the curatorship of Assoc. Prof. Dr.Lütfü Kaplanoğlu.

\section{Conclusion}

During the period from the beginning of the 2oth century until today, the modern life and the artwork as its yield led to questioning of artist and audience concepts repeatedly thanks to the changes / transformations experienced also in unique printmaking field as in the disciplines of art. From this perspective, the possibilities for expression of the existing language of art have become stronger and allow for an area where each individual has different mental / emotional processes. In particular, it increases the importance of workshops that trigger an interactive process in the workshop environment and focuses on the process of sharing the application dynamics of the professional artist with the participant. This is true in the art of Exlibris, which is seen in the position of a communication object and provides a functional quality as well as an emotional connection between the artist and the viewer.

With this basic approach, it will also be possible to increase the number
Image 13: International Istanbul Engravist Workshops Engravist Exhibition Poster, 2017 
of interested / informed viewers by organizing more activities in numerical sense, without ignoring the idea that workshops and exhibitions created for Ex-libris art have many advantages in terms of production and application simplicity, dimensions and wide sharing possibilities.

In the workshops and exhibitions held within the scope of International Engravist Printmaking Activities organized between 18-22 September 2017 under the project with the specialists in their field, providing Istanbul focused new visual and emotional gains not only for the participants but also for audiences is considered as a positive output of all these efforts.

\section{References}

Ardahanlı, O. (2015). Ekslibris Tasarımında Kadın Imgesi Yansımaları: Doğa, Müzik, Erotizm ve Mitoloji. Uluslararası Ekslibris Dergisi, 2/85-103. Engravist.com (2018). Uluslararası İstanbul Baskıresim Etkinlikleri. http:// www.engravist.art/, Retrieved on: 11.05.2018.

Engravist Sergi Kataloğu. (2017). Uluslararası İstanbul Baskıresim Etkinlikleri. İstanbul.

Feryal Beykal, F. (2012). ilköğretim ikinci Kademe Görsel Sanatlar Dersinde ÖzgünBaskıresim Uygulamalarına ilişkin Öğretmen Görüşleri. Pamukkale Üniversitesi Eğitim Fakültesi Dergisi, 31/189-201.

Fırıncı, M. (2013). Dijital Çağda Geleneksel Baskı Resim ve Teknikler Arası Geçiş (Melezleşme). Anadolu Ünv. sanat ve tasarım dergisi, 4/ 127-135. Karakaş, E. (2006). Gazi Eğitim Enstitüsü Resim-iss Bölümü 1932- 1980 Dönemi Linol Baskıresim Çalısmaları ve Nevzat Akoral. Yüksek Lisans Tezi. Abant i̇zzet Baysal Üniversitesi Sosyal Bilimler Enstitüsü, Bolu.

Kaynar, A. (2006). Kaynak ve Dayanaklarıyla Ex-libris ve Bir Örnek Sanatçı: Hasip Pektaş. Yüksek Lisans Tezi. Mustafa Kemal Üniversitesi, Sosyal Bilimler Enstitüsü, Hatay.

Okur, G. (2013). Iletişim Açısından Ex-libris. Anadolu Üniversitesi Sanat ve Tasarım Dergisi, 5/40-48.

Pektaş, H. (2014a), Ex-libris, Ankara: iED.

Pektaş, H. (2014b), Türkiye'de Ekslibris. Uluslararası Ekslibris Dergisi, 1/1-9. 